\title{
Performance of rabbits fed diets containing graded levels of processed tallow (Detarium microcarpum) seed meal
}

Jiya $^{1}$, E. Z., Ijaiya ${ }^{1}$, A. T., Olorunsanya ${ }^{2}$, A. O. and Ayanwale ${ }^{1}$, B.A.

${ }^{1}$ Deparment of Animal Production. Federal University of Technology Minna, Niger State,m Nigeria. ${ }^{2}$ Depatment of Animal Production. Ibrahim Babangida University Lapai Niger State, Nigeria.

*Corresponding author jiya.elisha@futminna.ng.com; ez_jiya@yahoo.com

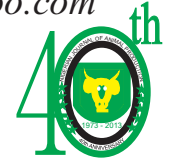

\section{Abstract}

A twelve weeks experiment was conducted using eighty one (81) cross bred (Chinchilla $x$ New Zealand white) weaned rabbits with average initial weights of $540 \mathrm{~g}$ to evaluate the performance of rabbits fed diets containing graded levels of processed tallow (Detarium microcarpum) seed meal. The design of the experiment was $1+2 / 4$ factorial and arranged as a completely randomized design (CRD). The rabbits were randomly allotted to nine treatment groups with nine rabbits per treatment. Each treatment had three replicates with three rabbits per replicate. Two processing methods (Cooking and Fermentation) were used to process tallow seeds. Control diet had 100\% palm kernel cake (PKC) meal and 0\% tallow seed meal, represented as $T_{0} . T_{1}-T_{4}$ contained cooked tallow seed meal (CTSM) and included as $T_{1}$ (75\% PKC : 25\% CTSM); $T_{2}\left(50 \%\right.$ PKC : 50\% CTSM); $T_{3}\left(25 \%\right.$ PKC : 75\% CTSM) and $T_{4}$ (0\% PKC : 100\% CTSM), While $T_{5}-T_{8}$ had fermented tallow seed meal (FTSM) and included at the same levels as observed in the cooked diets. Data were collected on body weight, feed intake, body weight gain, feed conversion ratio, protein efficiency ratio and nutrient digestibility were calculated. Only ash content was affected by the processing method in the result of nutrient digestibility. The results revealed that processing improves the nutritional quality of tallow seeds. Rabbits fed cooked tallow seed based diets revealed higher feed intake, final body weight and body weight gain compared to Rabbits fed diets containing fermented tallow seed. It was therefore concluded that cooking and fermentation methods are effective processing method for eliminating the anti-nutritional factors contained in tallow seeds and so can be included in the diets of weaned rabbits at $100 \%$ replacement of PKC without deleterious effect on their growth performance.

Keywords: rabbits, tallow seeds, cooking, fermentation, palm kernel cake, performance.

\section{Introduction}

Rabbits have the potential for filling the gap between demand and supply of animal protein in developing countries like Nigeria. This is because of its high genetic potential, short generation interval, high fecundity, rapid growth rate, high prolificacy and relatively low cost of production (Akinnusi et al., 2007). Rabbits are mainly raised for meat, skin and fur production, although they are also used as laboratory animals. Population of rabbits in Nigeria is estimated to be 1.7 million (Adama, 2008). Compared to other animal species, rabbit meat is considered a lean one that is rich in protein. Meat from rabbits of any age is highly appreciated for human consumption. It is a product that fits any taste. It is tender and of high culinary yield, easy and quick to cook. Above all rabbit's meat is a source of healthful food as it is low in cholesterol and good source of protein 
for coronary heart patients (Hernandez, 2004). With the soaring prices of beef, pork and poultry meat, more people may turn to rabbit as an alternative cheap source of animal protein. When cooked, rabbit meat is indistinguishable from chicken meat. Rabbit meat, compared to other meat sources, is very scarce in the meat shops. This scarcity may be a result of low level of production and/or problem of feed resource. Absence of specially formulated feeds for rabbits in Nigerian market is a major constraint to the expansion of the rabbit industry (Jiya, 2012). The competition between man and livestock particularly monogastrics for conventional feed ingredients such as grains is becoming increasingly stiffer there by increasing the cost of feeding in animal production. Increase in the cost and scarcity of conventional protein feed ingredients (groundnut cake, soybean meal, cotton seed cake, palm kernel cake and fish meal) calls for urgent need to investigate alternative but cheap protein sources as animal feed ingredients. However, these sources should not be competed for by man and should contain the required nutrients without compromising quality.

The major problem affecting the rabbit industry is the shortage of cheap quality feed stuffs. Feed accounts for more than 70 $\%$ of the total cost of production. Research has shown that the use of non-conventional feed stuffs in feeding non-ruminant livestock have good prospects in livestock industry. Ayanwale et al. (2001) used Colocassia esculentum, a non-conventional feed material in feeding rabbits, the results showed that Colocassia esculentum did not have any deleterious effect on rabbit performance. Palm kernel cake (PKC) have been widely used as a protein source in ruminants (Chandrazekriah et al., 2001), pig diets (Kim et al., 2001), broilers and rabbits (Onwudike 1986 and Aganga et al., 1991). Research have been undertaken to determine the quality of PKC and its maximum level in poultry diets (Perez et $a l ., 2000)$ and to replace other feedstuffs such as groundnut cake and soybean. PKC supplies both protein and energy. It has a crude protein of $18 \%$ which classified it as a protein source of medium grade (Chin, 2001). Palm kernel cake (PKC) and other agro by-products are classified as industrial by-products and are strategic feedstuffs used to supplement feed to livestock. The author also observed that in the past these feedstuffs were observed to be wastes and environmental pollutants. In recent times the agro industrial by-products have become expensive as they form bulk of ruminant diets and substantially included in the diets of monogastrics especially poultry. Palm kernel meals are found in large quantity in a number of tropical countries and are available at competitive prices. Four thousand tonnes of palm kernel meal were produced worldwide in 2002 (FAO, 2003). Bush plant's seeds like tallow (Detarium microcarpum) seeds can be used to replace palm kernel cakes which are also becoming inadequate in livestock feed industry. Tallow (Detarium microcarpum) is a leguminous plant found in dry savanna forests (Keay et al., 1964). The fruits are edible and rich in vitamin C. It is a high yielding tree and large quantities of tallow seed are left wasting every year in the bush. Tallow (Detarium microcarpum) seed is masked by anti-nutritional factors such as tannin, phytate, saponnin, cyanogenic glycoside and trypsin inhibitor (Anhwange etal., 2004).

If the anti- nutritional factors in tallow (Detarium microcarpum) seed are eliminated, it could replace PKC in a rabbit diet thus reducing the cost of production. The use of tallow seeds in rabbit production 
increase quality meats in the market and as well as increase the income of individual producers especially women and children thereby contributing to the nation's economy. Therefore this study was designed to investigate the performance of rabbits fed diets containing graded levels of processed tallow seed meal.

\section{Materials and methods}

\section{Preparation and processing of tallow (Detarium microcarpum) seed meal}

The quantities required for this experiment were sourced around Jima District in Lavun Local Government Area of Niger State, Nigeria, which is in the Southern Guinea Savanna. The seeds were obtained in the months of December to February, when they are abundant and labour cost for collection is usually minimal. About $50 \mathrm{~kg}$ of tallow (Detarium microcarpum) seeds were collected, cleaned,weighed and poured into a drum containing 50 litres of water. The water was boiled at $100^{\circ} \mathrm{C}$ and cooked for two hours according to the methods described by Kaankuka (1996). The second portion was milled using a hammer mill ( $2 \mathrm{~mm}$ sieve) and anaerobically fermented using the method described by (Annongu et al., 2004). It involved milling the seeds using hammer mill with sieve size of $2 \mathrm{~mm}$. The milled seeds were then soaked in a given quantity of water for 7 days after which the dough was removed and packed in doubled layered polytene bags and tied to exclude air. It was then placed in a drum, covered to make it air tight, and left to ferment for another 7 days. Both the cooked tallow and fermented tallow seed meal samples were sun-dried and stored in air-tight bags until ready for use.

\section{Experimental diets / management of rabbits}

The rabbits were randomly allotted to nine treatment groups with nine rabbits per treatment. Each treatment had three replicates with three rabbits per replicate. Two processing methods (Cooking and Fermentation) were used to process tallow seeds. Control diet had 100\% palm kernel cake (PKC) meal and $0 \%$ tallow seed meal, represented as $\mathrm{T}_{0} . \mathrm{T}_{1}-\mathrm{T}_{4}$ contained cooked tallow seed meal (CTSM) and included as $\mathrm{T}_{1}\left(75 \%\right.$ PKC : $25 \%$ CTSM); $\mathrm{T}_{2}(50 \%$ PKC : $50 \%$ CTSM); $\mathrm{T}_{3}(25 \%$ PKC : 75\% CTSM) and $\mathrm{T}_{4}(0 \%$ PKC : $100 \%$ CTSM $)$, While $\mathrm{T}_{5}-$ $\mathrm{T}_{8}$ had fermented tallow seed meal (FTSM) and included at the same levels as observed in the cooked diets (Table 2). The rabbits were placed in three-tier rabbit hutches which had a total of nine units per tier. The rabbits were provided with feed and water ad-libitum twice daily at 0800 and $1400 \mathrm{~h}$ for the 84 days experimental period. The rabbits were dewormed against endo and ecto-parasites using $10 \mathrm{mg} / \mathrm{ml}$ ivomectine ${ }^{\mathrm{R}}$ Pantex Holland). In addition, medication was administered when necessary. The diets were supplemented with equal quantities of forages (Tridax precumbens). The rabbits were weighed at the beginning of the experiment and subsequently on weekly basis. The parameters measured were daily feed intake, weekly body weight and final body weight. Feed conversion ratio (FCR) and Protein efficiency ratio (PER) were calculated from weight gain and feed intake values. On the $77^{\text {th }}$ day of 84 days of experimental period one rabbit per replicate was put in a metabolism cage and fed ad-libitum for three days during which period the rabbits got used to the environment. The rabbits were fasted for twent-four hours and thereafter fed $90 \%$ of their ad-libitum intake for five days. Feaces arising from the five days feeding plus that 
from another twenty-four hours fasting period were collected. This was to ensure total collection of feacal droppings associated with the feed consumed. Feacal droppings collected each day were oven dried at $60^{\circ} \mathrm{C}$, put in a plastic bag and stored in a refrigerator at the end, all droppings collected from each replicate were bulked together and samples taken for determination of proximate composition. Experimental feeds and feacal droppings were analyzed for proximate composition according to AOAC (2000) and used to calculate digestibility coefficient. Gross energy of feeds was determined in a Parr oxygen adiabatic bomb calorimeter. Apparent digestibility and coefficient of digestibility of the feed and the individual nutrients contained in it were calculated using the following formulae:

[(( Amount in feea consumed)- (Amout of Nutrient in faeces))/Amount in feed consumed] $\mathrm{x} 100$

\section{Proximate analysis}

Proximate and energy composition of the raw, cooked and fermented tallow seeds were determined according to AOAC (2000).

\section{Determination of anti-nutritional factors}

Trypsin inhibitor, phytate, tannins, cyanogenic glycoside and saponins were analyzed using AOAC (2000)

\section{Amino acid determination.}

The amino acid profiles of the raw, cooked and fermented tallow seeds were determined at the Bio-chemistry laboratory University of Jos, Plateeu State using the methods described by Spackman et al. (1958). The tallow seed samples were dried to constant weight, defatted, hydrolyzed and evaporated in a rotary evaporator and then loaded into the Technicon Sequential Multi sample amino acid analyzer(TSM).

\section{Data Analysis}

The data on average body weight, daily feed intake, feed conversion ratio, protein efficiency ratio and digestibility of various nutrient components of the diets were subjected to analysis of variance (ANOVA) (SAS 1998) .The design of the experiment was 1 plus $2 / 4$ factorial and arranged as a completely randomized design.

\section{Result and discussion}

The chemical composition of tallow (Detarium microcarpum) seed is presented in Table 2. The dry matter percentage of the fermented seed sample (95.70 \%) was significantly $(\mathrm{P}<0.05)$ higher than the raw $(92.00 \%)$ and cooked samples $(90.50 \%)$. The crude protein was significantly $(\mathrm{P}<0.05)$ lower in raw sample $(19.25 \%)$ with the fermented sample having the highest values $(22.05 \%)$. Crude fibre content of the cooked tallow seed $(10.60 \%)$ was significantly $(\mathrm{P}<0.05)$ lower compared to the fermented $(14.87 \%)$ and the raw (14.95\%) samples. Ash content was higher $(\mathrm{P}<0.05)$ in the raw sample $(3.50 \%)$ followed by the cooked sample $(1.50 \%)$ and the fermented sample $(1.00 \%)$. The values of ether extract showed significant $(\mathrm{P}<0.05)$ differences with the raw sample having the lowest value of $8.38 \%$ followed by the fermented sample $(9.00 \%)$, and the highest value $(10.00 \%)$ was observed in the cooked sample. Nitrogen free extract was significantly $(\mathrm{P}<0.05)$ higher in the fermented sample $(48.78 \%)$ followed by the cooked samples $(46.52 \%)$ and the lowest value (45.92\%) in the raw samples. Gross energy content of the seed samples showed that cooked sample had the highest significant $(\mathrm{P}<0.05)$ value $\quad(3555.00$ $\mathrm{Kcal} / \mathrm{kg}$ ) followed by the raw sample $(3306.00 \mathrm{Kcal} / \mathrm{kg}$ ) and the fermented sample $(3197.00 \mathrm{Kcal} / \mathrm{kg})$. The moisture content of the seeds was generally low. This 
Jiya, Ijaiya, Olorunsanya, and Ayanwale

Table.1 Composition of experimental diets fed to the weaned rabbits (4 to 5 weeks of age) (\%)

\begin{tabular}{|c|c|c|c|c|c|c|c|c|c|}
\hline & \multirow{2}{*}{$\begin{array}{l}\text { Control } \\
\mathrm{T}_{0}\end{array}$} & \multicolumn{4}{|c|}{ Cooked tallow seed meal (CTSM) } & \multicolumn{4}{|c|}{ Fermented tallow seed meal (FTSM) } \\
\hline & & $\mathrm{T}_{1}$ & $\mathrm{~T}_{2}$ & $\mathrm{~T}_{3}$ & $\mathrm{~T}_{4}$ & $\mathrm{~T}_{5}$ & $\mathrm{~T}_{6}$ & $\mathrm{~T}_{7}$ & $\mathrm{~T}_{8}$ \\
\hline \multicolumn{10}{|c|}{ Ingredient composition } \\
\hline Maize & 16.59 & 22.40 & 26.04 & 31.10 & 34.08 & 23.67 & 29.21 & 32.86 & 36.65 \\
\hline Palm kernel cake & 58.06 & 39.20 & 24.31 & 10.89 & 0.00 & 38.24 & 22.72 & 10.45 & 0.00 \\
\hline Tallow seed meal & 0.00 & 13.07 & 24.31 & 32.66 & 40.57 & 12.75 & 22.72 & 31.35 & 38.00 \\
\hline Maize offal & 20.00 & 20.00 & 20.00 & 20.00 & 20.00 & 20.00 & 20.00 & 20.00 & 20.00 \\
\hline Salt & 0.50 & 0.50 & 0.50 & 0.50 & 0.50 & 0.50 & 0.50 & 0.50 & 0.50 \\
\hline $\begin{array}{l}\text { Vitamin Mineral } \\
\text { premix }\end{array}$ & 0.25 & 0.25 & 0.25 & 0.25 & 0.25 & 0.25 & 0.25 & 0.25 & 0.25 \\
\hline Bone meal & 3.00 & 3.00 & 3.00 & 3.00 & 3.00 & 3.00 & 3.00 & 3.00 & 3.00 \\
\hline Coccidiostat & 0.10 & 0.10 & 0.10 & 0.10 & 0.10 & 0.10 & 0.10 & 0.10 & 0.10 \\
\hline Methionine & 0.25 & 0.25 & 0.25 & 0.25 & 0.25 & 0.25 & 0.25 & 0.25 & 0.25 \\
\hline Lysine & 0.25 & 0.25 & 0.25 & 0.25 & 0.25 & 0.25 & 0.25 & 0.25 & 0.25 \\
\hline Total & 100 & 100 & 100 & 100 & 100 & 100 & 100 & 100 & 100 \\
\hline \multicolumn{10}{|c|}{ Determined analysis (\%) } \\
\hline Dry matter & 88.47 & 87.50 & 89.05 & 87.95 & 87.88 & 88.89 & 88.69 & 89.13 & 87.85 \\
\hline Crude Protein & 16.85 & 16.48 & 16.20 & 16.65 & 16.00 & 16.55 & 16.20 & 16.85 & 16.00 \\
\hline Crude Fibre & 15.62 & 16.12 & 16.50 & 15.50 & 15.50 & 15.50 & 16.60 & 16.03 & 16.03 \\
\hline Ash & 4.50 & 4.50 & 4.50 & 4.00 & 4.00 & 4.00 & 4.50 & 5.00 & 5.50 \\
\hline Ether extract & 9.00 & 11.00 & 11.00 & 10.50 & 9.50 & 10.50 & 9.00 & 9.00 & 9.50 \\
\hline NFE & 42.50 & 48.40 & 48.40 & 43.01 & 42.88 & 43.01 & 42.39 & 42.28 & 40.85 \\
\hline $\begin{array}{l}\text { Energy kcal/kg } \\
\text { (ME) }\end{array}$ & 2756 & 2840 & 2864 & 2941 & 2891 & 2842 & 2846 & 2615 & 2749 \\
\hline
\end{tabular}

Note $\mathrm{T}_{0}=100 \%$ PKC meal; $\mathrm{T}_{1}=75 \%$ PKC: $25 \%$ CTSM; $\mathrm{T}_{2}=50 \%$ PKC: $50 \%$ CTSM $; \mathrm{T}_{3}=25 \%$ PKC: $75 \%$ CTSM; $\mathrm{T}_{4}=0$

$\%$ PKC: $100 \%$ CTSM $; \mathrm{T}_{5}=75 \%$ PKC: $25 \%$ FTSM $; \mathrm{T}_{6}=50 \%$ PKC: $50 \%$ FTSM $; \mathrm{T}_{7}=25 \%$ PKC: $75 \%$ FTSM $; \mathrm{T}_{8}=0 \%$ PKC: $100 \%$ FTSM

Vitamin Mineral Premix supplied per $2.5 \mathrm{~kg}$ contains: Retinol acetate (10000000 iu), Vit. $\mathrm{D}_{3}(2000000 \mathrm{iu})$, Vit E ( $\left.15000 \mathrm{iu}\right)$, Vit B (3000mg),Niacin (15000mg), Calcium pantothenate (800mg), Vit . $B_{6}(3000 \mathrm{mg})$, Vit. $B_{12}(10 \mathrm{mg})$ Vit. $K_{3}(2000 \mathrm{mg})$, Biotin (20gm), Folic acid (500mg), Choline chloride (250,000mg), Manganese (75000mg), Iron (25000mg), Copper (5000mg), Zinc $(70000 \mathrm{mg})$, Selenium $(150 \mathrm{mg})$, lodine $(1300 \mathrm{mg})$, Magnesium $(100 \mathrm{mg}), 500 \mathrm{~g}$ ethoxyquin and BHT $(700 \mathrm{~g})$

$=$ Nitrogen free extract. 
Table 2: Proximate composition and energy contents of raw, cooked and soaked andfermented tallow (Detarium microcarpum) seeds

\begin{tabular}{lllll}
\hline Parameters (\%) & Raw & Cooked & Fermented & SEM \\
\hline Dry Matter & $92.00^{\mathrm{b}}$ & $90.50^{\mathrm{c}}$ & $95.70^{\mathrm{a}}$ & 0.01 \\
Crude Protein & $19.25^{\mathrm{c}}$ & $21.88^{\mathrm{b}}$ & $22.05^{\mathrm{a}}$ & 0.01 \\
Crude Fiber & $14.95^{\mathrm{a}}$ & $10.60^{\mathrm{c}}$ & $14.87^{\mathrm{b}}$ & 0.01 \\
Ash & $3.50^{\mathrm{a}}$ & $1.50^{\mathrm{b}}$ & $1.00^{\mathrm{c}}$ & 0.01 \\
Ether Extract & $8.38^{\mathrm{c}}$ & $10.00^{\mathrm{a}}$ & $9.00^{\mathrm{b}}$ & 0.01 \\
NFE & $45.92^{\mathrm{c}}$ & $46.52^{\mathrm{b}}$ & $48.78^{\mathrm{a}}$ & 0.01 \\
Gross energy ( Kcal/Kg) & $3300.60^{\mathrm{b}}$ & $3555.00^{\mathrm{a}}$ & $3197.00^{\mathrm{c}}$ & 0.58 \\
\hline abc Means with different superscripts in the same row are significantly $(\mathrm{P}<0.05)$ different.
\end{tabular}

is an indication that the seeds whether raw or processed could be stored for a long time without growing mouldy, as the moisture content values were below the $15 \%$ required as safe storage limit for plant food materials (Eromosele and Eromosele, 1993; Anhwange et al., 2004). The same observation was made by Obun et al. (2011) who reported that dry heating of seeds seemed to concentrate the nitrogenous compounds in the beans by removing most of the water molecules thus increasing the dry matter, crude protein and ether extract contents. The low ash content in both the cooked and fermented samples of tallow could be attributed to leaching of the mineral during cooking or fermentation as both were done in water medium and is in line with the report of Mubarak (2005) who observed leaching of mineral ash in processed mung bean (Phaseolus aureus) seeds. The values observed for nitrogen free extract in both the fermented and the cooked seeds fall within the range reported by Okorie and Amechi (2003), who reported the proximate composition of some selected tropical legumes. Processing tends to increase the energy content of tallow seeds. The values showed that though it is a leguminous plant, it can also be used as an energy source in the diets of rabbits.

The effects of processing on anti-nutritional factors of tallow seed is presented in Table 3. Levels of tanin, phytate, saporin, cyanogenic glycoside and trypsin inhibitor

Table.3: Effect of tallow (Detarium microcarpun) seed processing on anti nutrients content

\begin{tabular}{lllllll}
\hline Parameter $(\mathrm{mg} / 100 \mathrm{~g})$ & Raw & Cooked & $(\% \mathrm{Rd})$ & $\begin{array}{l}\text { Soaked } \\
\text { andFermented }\end{array}$ & $\begin{array}{l}(\% \\
\mathrm{Rd})\end{array}$ & SEM \\
\hline Tanin & $68.90^{\mathrm{a}}$ & $20.00^{\mathrm{b}}$ & 71.00 & $18.60^{\mathrm{c}}$ & 73.00 & 0.006 \\
Phytate & $121.00^{\mathrm{a}}$ & $68.00^{\mathrm{b}}$ & 43.80 & $20.00^{\mathrm{c}}$ & 83.50 & 0.58 \\
Saponin & $37.00^{\mathrm{a}}$ & $25.50^{\mathrm{b}}$ & 31.11 & $12.50^{\mathrm{c}}$ & 66.20 & 0.33 \\
Cyanogenic glycoside & $0.40^{\mathrm{a}}$ & $0.08^{\mathrm{b}}$ & 80.00 & $0.04^{\mathrm{c}}$ & 90.00 & 0.006 \\
Trypsin Inhibitor (TUI) & $303.00^{\mathrm{a}}$ & $102.00^{\mathrm{b}}$ & 66.30 & $56.00^{\mathrm{c}}$ & 81.50 & 0.58 \\
\hline $\begin{array}{l}\text { abc Means with different superscripts in the same row are significantly (P<0.05) different. } \\
\text { SEM= standard error of mean. }\end{array}$ \\
$\begin{array}{ll}\text { LOS= Level of significance } \\
\text { Rd= reduction }\end{array}$
\end{tabular}


in the raw tallow seeds were reduced $(\mathrm{P}<0.05)$ by cooking and fermentation in that order. The significant reduction in the contents of tannin, phytate, saponin, cyanogenic glycocide and trypsin inhibitor are in line with the reports of Apata (2003) and Soetan and Oyewale (2009). The authors in their review reported that cooking and fermentation are effective processes to eliminate resistant antinutritional factors.

The results of amino acid composition of raw, cooked and fermented tallow (Table 4) revealed that the amino acid content of the seeds was $(\mathrm{P}<0.05)$ affected by the processing of the seeds. Raw and cooked seeds were $(\mathrm{P}<0.05)$ higher in arginine, than the fermented seeds, however the raw seeds were $(\mathrm{P}<0.05)$ higher in aspartic acid, serine, glutamic acid, proline, glycine, alanine, cystine valine, leucine and phenyl alanine than cooked and fermented seeds.
Threonine and thyrosine were higher in cooked than in fermented or raw samples, while the fermented samples also had higher $(\mathrm{P}<0.05)$ values of lysine, histidine, proline, methionine and isoleucine compared to the cooked and the raw. Alanine was similar in raw and fermented but differ $(\mathrm{P}<0.05)$ from the cooked.

The processing methods affected the amino acid profile of tallow seed. The improvement in the content of the amino acid showed that processing unleashes amino acids trapped by the anti-nutrients as was observed by Ari (2006); the author used different processing methods to determine the nutritional content of soybean and concluded that cooking gave improved amino acid contents of soybean.

Growth performance of rabbits fed processed tallow seed meal based diets are presented in Table 5. Final body weight, average daily body weight gain, average

Table 4: Amino acid content of raw, cooked and fermented tallow (Detarium microcarpum) seed

\begin{tabular}{lllll}
\hline Parameter $(\mathrm{g} / 100 \mathrm{~g}$ protein $)$ & Raw & Cooked & Fermented & SEM \\
\hline Lysine & $3.06^{\mathrm{b}}$ & $3.00^{\mathrm{c}}$ & $3.60^{\mathrm{a}}$ & 0.01 \\
Histidine & $2.01^{\mathrm{c}}$ & $2.51^{\mathrm{b}}$ & $2.69^{\mathrm{a}}$ & 0.01 \\
Aginine & $4.51^{\mathrm{a}}$ & $4.51^{\mathrm{a}}$ & $4.25^{\mathrm{b}}$ & 0.01 \\
Aspartic acid & $9.60^{\mathrm{a}}$ & $7.25^{\mathrm{c}}$ & $8.98^{\mathrm{b}}$ & 0.01 \\
Threonine & $2.66^{\mathrm{c}}$ & $3.30^{\mathrm{a}}$ & $2.94^{\mathrm{b}}$ & 0.01 \\
Serine & $3.23^{\mathrm{a}}$ & $2.25^{\mathrm{c}}$ & $2.83^{\mathrm{b}}$ & 0.01 \\
Glutamic acid & $11.23^{\mathrm{a}}$ & $7.49^{\mathrm{c}}$ & $8.60^{\mathrm{b}}$ & 0.01 \\
Proline & $2.65^{\mathrm{b}}$ & $2.55^{\mathrm{c}}$ & $2.97^{\mathrm{a}}$ & 0.01 \\
Glysine & $4.11^{\mathrm{a}}$ & $4.08^{\mathrm{b}}$ & $3.50^{\mathrm{c}}$ & 0.01 \\
Alanine & $4.63^{\mathrm{a}}$ & $3.70^{\mathrm{b}}$ & $4.63^{\mathrm{a}}$ & 0.01 \\
Cystine & $1.19^{\mathrm{a}}$ & $0.79^{\mathrm{c}}$ & $1.06^{\mathrm{b}}$ & 0.01 \\
Valine & $4.30^{\mathrm{a}}$ & $3.37^{\mathrm{c}}$ & $4.18^{\mathrm{b}}$ & 0.01 \\
Methionine & $0.86^{\mathrm{c}}$ & $1.04^{\mathrm{b}}$ & $1.25^{\mathrm{a}}$ & 0.01 \\
Isoleucine & $3.20^{\mathrm{b}}$ & $3.08^{\mathrm{c}}$ & $3.51^{\mathrm{a}}$ & 0.01 \\
Leucine & $7.19^{\mathrm{a}}$ & $5.49^{\mathrm{c}}$ & $6.15^{\mathrm{b}}$ & 0.01 \\
Thyrosine & $2.70^{\mathrm{c}}$ & $3.22^{\mathrm{a}}$ & $2.90^{\mathrm{b}}$ & 0.01 \\
Phenylalanine & $4.08^{\mathrm{a}}$ & $3.89^{\mathrm{c}}$ & $4.06^{\mathrm{b}}$ & 0.01 \\
\hline abc Means with different superscripts in the same row are significantly (P<0.05) different & \\
SEM= standard error of mean & & & &
\end{tabular}


daily feed intake, feed conversion ratio and protein efficiency ratio were $(\mathrm{P}<0.05)$ higher for rabbits fed the cooked diets than the fermented diets. Final body weight decreased significantly $(\mathrm{P}<0.05)$ at an inclusion of $75 \%$. Daily feed intake gradual reduced as the inclusion level increased. Though $75 \%$ and $100 \%$ levels were similar, protein efficiency ratio was higher at $100 \%$ inclusion level compared to all other levels which were not significantly $(\mathrm{P}>0.05)$ different. Interaction between the method and levels was not $(\mathrm{P}>0.05)$ different for final body weight, average daily body weight gain, average daily feed intake, feed conversion ratio and protein efficiency ratio.

The better performance recorded for rabbits on diets containing the cooked test ingredient might be an indication that cooking destroyed the anti-nutritional factors in tallow seeds more effectively than soaking and fermentation, thereby improving nutrient availability for better performance as reported by Amaefule and Obioha (2001) who fed raw and boiled pigeon pea seed meal to broilers and Obun et al. (2008) and Obun and kehinde (2011). The authors fed Detarium microcarpum seed meal to broiler finishers. Lower final body weight obtained at $75 \%$ and $100 \%$ levels could be as result of the gradual decrease in feed intake could be that the rabbits met their energy requirement or the presence of anti-nutrients in tallow seed meal might have affected the bioavailability of nutrients which might be an indication that processing did not completely eliminate the anti-nutrients. This also agrees with the report of Ahamefule (2005) and Anya et al. (2011) who worked with pigeon pea and African yam bean respectively.

Nutrient digestibility of rabbits fed processed tallow (Detarium microcarpum) seed meal is shown in Table 6. Processing and level of inclusion of tallow seed meal had no $(\mathrm{P}>0.05)$ effect on dry matter, crude fibre, ether extract and nitrogen free extract digestibility. Ash was $(\mathrm{P}<0.05)$ affected by the processing methods with the fermented diets having a higher $(\mathrm{P}<0.05)$ value $(82.36$ $\%)$ than cooked $(76.84 \%)$. There were nosignificant $(\mathrm{P}>0.05)$ differences in the levels of inclusion. Interactive effect between the processing method and levels of inclusion was also not significantly $(\mathrm{P}>0.05)$ different. Although the diets were generally digestible, rabbits fed diets containing soaked and fermented tallow seed meal had higher ash digestibility compared to those fed diets containing cooked tallow seed meal. This might be as a result of high reduction of phytic acid content of the soaked and fermented seeds as explained in the findings of Obun et al. (2011). Phytic acid can bind to mineral elements to form complexes that are indigestible thereby decreasing the bioavailability of mineral elements in the diets of broilers.

\section{Conclusion}

Therefore, it was concluded that tallow seed is of good nutritional quality if the antinutritional factors are eliminated. Cooking and soaking and fermentation methods are effective processes of eliminating antinutritional factors present in tallow seed. However, cooking gave better results than soaking and fermentation methods. Cooked tallow seed meal can be included in the diets of rabbits of rabbits up to $100 \%$ without any deleterious effect. Soaked and fermented tallow seed meal can be included in the diets of rabbits at $50 \%$ levels. Further researches should seek to explore other processing methods on tallow seed with the aim of making it more available not only for rabbits but the entire livestock production in order to solve the acute problem of feed 
Table 5: Growth Performance of rabbits fed diets containing graded levels of processed tallow seed meal

\begin{tabular}{|c|c|c|c|c|c|c|}
\hline Parameter & Ibwt (g) & Fbwt (g) & Av.d bwg 9g) & Av.d.fi (g) & FCR & PER \\
\hline Cooked & 544.22 & $1402.99^{\mathrm{a}}$ & $10.22^{\mathrm{a}}$ & $64.74^{\mathrm{a}}$ & $7.40^{\mathrm{a}}$ & $0.98^{\mathrm{a}}$ \\
\hline $\begin{array}{l}\text { Soaked and } \\
\text { Fermented }\end{array}$ & 543.07 & $1242.27^{b}$ & $8.32^{b}$ & $60.67^{b}$ & $6.37^{b}$ & $0.84^{\mathrm{b}}$ \\
\hline SEM & 6.89 & 26.05 & 0.31 & 1.27 & 0.22 & 0.03 \\
\hline $\begin{array}{l}\text { LOS } \\
\text { Level }\end{array}$ & NS & $*$ & $*$ & $*$ & $*$ & $*$ \\
\hline 0 & 545.22 & $1386.67^{\mathrm{a}}$ & $10.02^{\mathrm{a}}$ & $73.00^{\mathrm{a}}$ & 7.32 & $0.81^{\mathrm{b}}$ \\
\hline 25 & 542.89 & $1382.42^{\mathrm{a}}$ & $9.99^{\mathrm{a}}$ & $69.44^{\mathrm{a}}$ & 7.03 & $0.90^{\mathrm{b}}$ \\
\hline 50 & 545.28 & $1325.70^{\mathrm{ab}}$ & $9.29^{\mathrm{ab}}$ & $62.86^{\mathrm{b}}$ & 6.79 & $0.91^{\mathrm{ab}}$ \\
\hline 75 & 544.55 & $1239.33^{\mathrm{b}}$ & $8.27^{\mathrm{b}}$ & $55.20^{\mathrm{c}}$ & 6.79 & $0.92^{\mathrm{ab}}$ \\
\hline 100 & 540.28 & $1279.03^{\mathrm{ab}}$ & $8.79^{\mathrm{ab}}$ & $55.20^{\mathrm{c}}$ & 6.79 & $1.04^{\mathrm{a}}$ \\
\hline SEM & 10.90 & 41.19 & 0.49 & 2.01 & 0.35 & 0.04 \\
\hline LOS & NS & $*$ & $*$ & $*$ & NS & $*$ \\
\hline Mx L & NS & NS & NS & NS & NS & NS \\
\hline
\end{tabular}

Table 6: Nutrient digestibility of rabbits fed processed tallow seed meal diets (\%)

\begin{tabular}{|c|c|c|c|c|c|c|}
\hline Method & DM & $\mathrm{CP}$ & $\mathrm{CF}$ & Ash & $\mathrm{EE}$ & NFE \\
\hline Cooked & 81.18 & 81.87 & 85.00 & $76.84^{b}$ & 92.51 & 79.67 \\
\hline Soaked and & 84.45 & 82.56 & 82.40 & $82.36^{\mathrm{a}}$ & 93.34 & 82.45 \\
\hline \multicolumn{7}{|l|}{ Fermented } \\
\hline SEM & 1.37 & 1.39 & 1.24 & 1.60 & 0.51 & 1.38 \\
\hline LOS & NS & NS & NS & $*$ & NS & NS \\
\hline \multicolumn{7}{|l|}{ Level } \\
\hline 0 & 80.50 & 80.18 & 81.25 & 76.92 & 91.60 & 79.81 \\
\hline 25 & 81.22 & 84.15 & 82.46 & 78.67 & 93.25 & 80.81 \\
\hline 50 & 85.09 & 83.64 & 86.65 & 82.46 & 93.51 & 83.24 \\
\hline 75 & 81.99 & 79.76 & 82.16 & 77.25 & 92.38 & 78.72 \\
\hline 100 & 85.26 & 84.34 & 85.98 & 82.71 & 93.91 & 84.17 \\
\hline SEM & 2.16 & 2.19 & 1.97 & 2.54 & 0.81 & 2.18 \\
\hline LOS & NS & NS & NS & NS & NS & NS \\
\hline $\mathrm{MxL}$ & NS. & NS & NS & NS & NS & NS \\
\hline
\end{tabular}


in the sector.

\section{Acknowledgements}

The authors wish to acknowledge the permission of the Federal University of Technology Minna for allowing them access to the farm facilities to conduct this research.

\section{Reference}

Adama, T. Z. 2008. Towards adequate animal protein intake by year 2020 . Inaugural lecture series 11. $24^{\text {th }}$ April, 2008. Federal University of Technology Minna, Niger State.

Ahamefule, F. O. 2005. Evaluation of pigeon pea-cassava based diets for goat production in South-Eastern Nigeria. Unpublished Ph.D Thesis. Departmentof Animal Production and Livestock Management, Michael Okpara University of Agriculture, Umudike, Nigeria. Pp20-35.

Aganga, A. A., Abdulmalik, M. and Sekoni, A. 1991. The effect of different protein sources and their levels on the production of breeding rabbits. Journal of Applied Rabbit Research, 14:30-33.

Akinnusi, F. A. O., Bamgbose, M., Sogunle, O. M., Oso, A. O. and Afolabi, F. O. 2007. Comparative effect of different animal protein concentrate on the carcass quality of rabbits. In:E. A. Agiang, L. N.Agwunobi and O. O. Olawoyin. Proceedings of the $32^{\text {nd }}$ Annual conference of the Nigeria Society for Animal production march 18-21, 2007 University of Calabar, Cross River State, Nigeria.

Akpata,D. F., 2003. "Biochemical and nutririve toxicological assessment of some tropical legume seeds." Unpublished Ph.D thesis, Department of Biochemistry, Faculty of Agriculture, University of Ibadan. Nigeria.

Amaefule, K. U. and Obioha, F. C. 2001. Performance of broiler starters fed raw and boiled pigeon pea seed meal. Nigerian Journal of Animal Production.28:34

Anhwange, B. A., Ajibola, V. O. and Oniye, S., 2004. Chemical studies of Moringa oleifera and Detarium microcarpum seeds. Journal of Biological Sciences 4(6):711-715.

Annongu, A. A., Joseph, J. K. and Liebert, F. 2004. Effect of anerobic fermentation and lyle treated Propopis Africana seed meal on the nutritional and haematological responses of harco chicks. Jourmal of Raw Material Research 1:33-41.

Anya, M. I., Ayuk, A. A., Umoren, E. P., Akpojovwo, V. A. and Ubua, J. 2011. Performance of weaned rabbits fed graded levels of yambean in cassava peal meal based diets. In: A. O Aduku, T. Oluwagbemi, S. O.Aribido, S. I. Daikoand O. J. Saliu. Research and Value-Addition: Key to Transformation of the Nigerian Livestock Industry. Proc.16 ${ }^{\text {th }}$ Annual Conference Animal Science Association of Nigeria (ASAN). September1 $2^{\text {th }}-15^{\text {th }} 2011$ Kogi State University, Anyigba, Kogi State. 274277.

Ayanwale, B. A., Adama, T. Z. and Jiya, E. Z. 2001. Growth and nutrient digestibility of rabbits fed Colocasia esculentum and Mangifera indica leaves. Journal of Science. Technology and Mathematics Education 4(1) 171178.

AOAC., 2000. Official method of analysis of the Association of Official Analytical Chemistry, $17^{\text {th }}$ edn. 
Washinton, D.C.

Ari, M. M., 2006. An evaluation of the effect of various processing methods on utilization of soyabean (Glycine max) by broiler chickens.Unpublished Ph.D thesis. Department of Animal Production. Federal University of Technology. Minna Niger State, Nigeria.

Chadrazekriah, M., Sampath, K. T., Thulasi, A. and Anadam, S. 2001. Insitu protein degradability of certain feedstuffs in cattle. Indian. Journal of Animal Science, 261-264.

Chin, F. Y. 2001. Palm Kernel Cake (PKC) as supplement for fattening Dairy cattle. In: Malaysia on feed resources for S. E. Asia. Manado, Indonesia.

Eromosele, I. C. and Eromosele, C. O. 1993. Plant Food for Human Nutrition (Netherland) 43(3) 251-258.

FAO 2003. The state of food insecurity in the world. 2003, Rome, Italy. (ㅁ)

Hernández, P. 2004. Calidad nutricional de la carne de conejo. Cunicultura 1: 17-21. quality and major factors influencing the rabbit carcass and meat quality. Livestoc Production Science., 75: 11-32.

Jiya, E. Z. 2012. Performance and organoleptic qualities of rabbits fed diets containing graded levels of processed tallow (Detarium microcarpum) seed Meal. Unpublished Ph.D thesis. Department of Animal Production. Federal University of Technology. Minna Niger State, Nigeria.

Kaankuka, F. G., Balogun, T. F. and Tegbe, T. S. B. 1996. Effect of duration of cooking of fullfat soybean on proximate analysis, levels of antinutritional factors, and digestibility by weaning pigs . Anim. Feeds. Sci. and Tech. (62): 229-237.
Keay, R. W. J. Onochie, C. F. A and Stanfield, D. P. 1964. Nigeria Trees. National press Ltd.Forest Research Institute of Nigeria(FRIN) Ibadan, vol.2.

Kim, B. G., Lee, J. H. ,Jung, H. J., Han, Y. K., Park, K. M. and Han, I. K. 2001. Effect of partial replacement of soybean meal with palm kernel meal and copra meal on growth performance, nutrient digestibility and carcass characteristics of finishing pigs. Asian Australasian. Journal of Animal Science, 14: 821-830.

Mubarak, A. E., 2005. Nutritional composition and antinutritional factors of mung bean seeds (Phaseolus aureus) as affected by some traditional processes. Food Chemistry. 89: 489495.

Obun, C. O., Olafadehan, O. A., Ayanwale, B. A. And Inuwa, M. 2008. Growth, carcass and organ weights of finisher broilers fed differently processed Detarium microcarpum seed meal (DMSM). Livestock Research for Rural Development, 20(8) 1-7.

Obun, C. $O$ and Kehinde, A. S., 2011. Effect of different methods of processing tallow (Detarium microcarpum, hull and sperr) seeds on Amino acid profile and mineral constituents. In:A.O Aduku, T. Oluwagbemi, S.O.Aribido,S. I. Daikoand O.J. Saliu.Research and Value-Addition: Key to Transformation of the Nigerian Livestock Industry. Proceedings of $16^{\text {th }}$ Annual Conference. AnimalScience Associationof Nigeria. (ASAN) 12 $15^{\text {th }}$ September 2011. Kogi State University Kogi State. Pp 104- 107.

Obun C. O., Yahaya, M. S., Kibon, A and Ukim, C., 2011. Effect of dietary 
Performance of rabbits fed diets containing graded levels of processed tallow seed meal

inclusion of raw Detarium microcarpum seed meal on performance and carcass and organ weights of broiler chicks. American Journal of Food and Nutrition. 1 (3) 128-135

Okorie, S. U and Amaechi,E. C., 2003. Effects of roasting and soaking on the proximate composition and fractional properties of selected tropical legumes. Global Journal of Pure and Applied Science, 9(2): 177-182.

Onwudike, O. C. 1986. Palm kernel meal as a food for poultry. Replacement of groundnut cake by palm kernel meal in broiler diets. Animal Feed Science Technology. 16:195-120.

Perez, J. F., Gernat,A. G. and Murillo,
J.G. 2000. The effect of different levels of palm kernel meal in layers diets. Poultry Science, 79: 77-79.

SAS. 1998. Stastical Analysis System Institutes. User's guide. SAS Institute Inc. Cary, N. C.

Soetan, K O and Oyewole, O. E., 2009. The need for adequate processing to reduce the anti-nutritional factors in plants used as human foods and animal feeds: A review. African Journal of Food Science 3(9): 223-232

Spackman, D. H., Stein, H. N. and Moore, S., 1958. .Automatic recording apparatus for use in chromatography of amino acid. Journal Analytical Chemistry 30:1990-1991.

Received: 14/04/13 Accepted: 27/09/13 